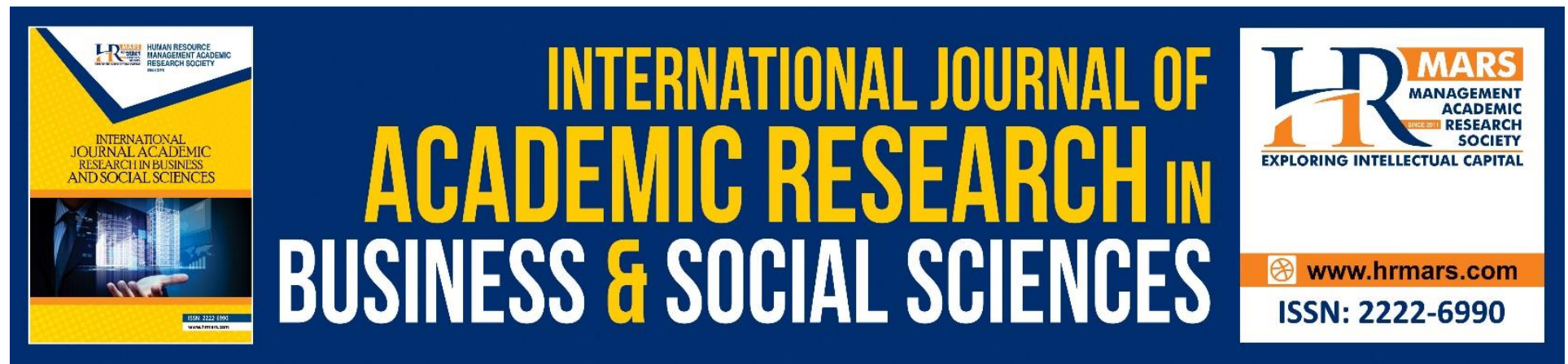

\title{
Work-Related Stress and Coping Strategies: A Systematic Literature Review
}

Farah Shazlin Johari

To Link this Article: http://dx.doi.org/10.6007/IJARBSS/v10-i6/7469

DOI:10.6007/IJARBSS/v10-i6/7469

Received: 01 April 2020, Revised: 02 May 2020, Accepted: 05 June 2020

Published Online: 20 June 2020

In-Text Citation: (Johari, 2020)

To Cite this Article: Johari, F. S. (2020). Work-Related Stress and Coping Strategies: A Systematic Literature Review. International Journal of Academic Research in Business and Social Sciences, 10(6), 1016-1032.

Copyright: (C) 2020 The Author(s)

Published by Human Resource Management Academic Research Society (www.hrmars.com)

This article is published under the Creative Commons Attribution (CC BY 4.0) license. Anyone may reproduce, distribute, translate and create derivative works of this article (for both commercial and non-commercial purposes), subject to full attribution to the original publication and authors. The full terms of this license may be seen

at: $\underline{\text { http://creativecommons.org/licences/by/4.0/legalcode }}$

Vol. 10, No. 6, 2020, Pg. $1016-1032$

http://hrmars.com/index.php/pages/detail/IJARBSS

JOURNAL HOMEPAGE

Full Terms \& Conditions of access and use can be found at http://hrmars.com/index.php/pages/detail/publication-ethics 


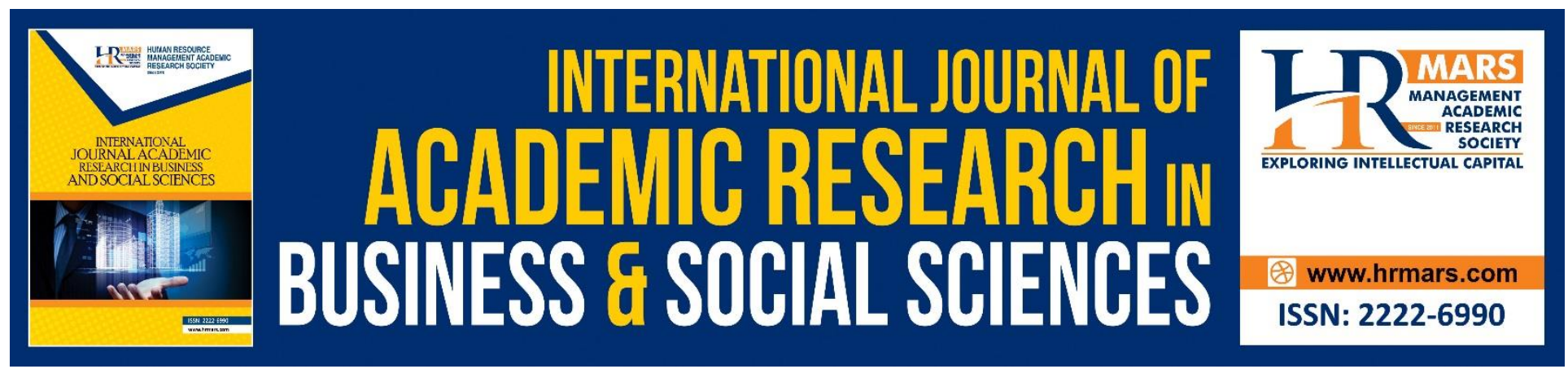

\title{
Work-Related Stress and Coping Strategies: A Systematic Literature Review
}

\author{
Farah Shazlin Johari \\ Faculty of Business and Management, Universiti Teknologi MARA
}

\begin{abstract}
While the issue of work-related stress has gained increasing attention as an important construct in Western literature, coping strategies concurrently have never been comprehensively reviewed in Asian tradition. The purposes of this review are to investigate work-related stressors across occupations and coping strategies used by these various occupations in reduction the stressful environment. The reviewed articles were obtained from three main databases; Web of Science, Scopus and Medline. Keywords including "stress", "work-related stress", "work stress", "occupational stress", coping strategies", "coping skills", "coping", and "coping mechanisms" were resulted from 14 articles that met the specified criteria. Main stressors identified in this review including workload, role ambiguity, responsibility, lack of job control, poor physical environment, conflict, interpersonal relationship and management. While, common coping strategies were utilized by employees were problem-focused coping, emotion-focused coping and coping resources. The present evidence is limited, and numerous research is needed on stress and coping strategies in the future to broaden its impact on work and health-related outcomes.
\end{abstract}

Keywords: Work-Related Stress, Stressor, Coping Strategies, Asian, Systematic Literature Review.

\section{Introduction}

For several decades, a plethora of stress studies have been dominating in the Western tradition. But, to date, the unresolved work-related stress is remaining debatable in literature. Some scholars claim terms and definitions of stress, occupational stress, work-related stress and job stress are conceptualized differently, but they are grounded in the same meaning (Larson, 2004; Reddy \& Poornima, 2012; Teixeira, 2014). Accordingly, the definition of work-related stress was first defined by World Health Organization (WHO) as an employee's reaction whenever they are challenged by assigned job responsibilities that do not correspond to their knowledge, skills and abilities (WHO, 1948). In more contemporary perspective, the National Institute for Occupational Safety and Health (2014) also acknowledges that work-related stress refers to the harmful physical and emotional reactions that often occur when job demands are not in line with an employee's capabilities, resources or needs. In this sense, work-related stress is important 
INTERNATIONAL JOURNAL OF ACADEMIC RESEARCH IN BUSINESS AND SOCIAL SCIENCES

Vol. 10, No. 6, June, 2020, E-ISSN: 2222-6990 @ 2020 HRMARS

because it significantly affects both employees and organizations in negative ways (Bahari et al., 2016).

The effect of work-related stress is influenced by the negative perceptions of the nature of stressors (Tuckey et al., 2015). Due to greater demands in today's competitive workforce, workrelated stressors are unique to numerous occupations. Working in different environments can cause similar occupations to be affected by various work-related stressors such as heavy workload, conflicts with other colleagues, lack of job control, job insecurity, lack of reward, poor working environment and management support (Kamarulzaman et al., 2017; Yim et al., 2018; Yang et al., 2017; Park \& Kim, 2013; Ren et al., 2018). Thus, neglecting these work-related stress issues can result in low job satisfaction, psychological stress, poor mental and physical well-being, high absenteeism, rates of change and intentions to quit, accidents and errors, and burnout. All of these, will consequently, impact on the overall functioning and profitability of the organization (Sackey and Sanda, 2009).

Even though work-related stress cannot be eliminated from everyday life, appropriate ways of coping with stress can be practiced in order to reduce it. Through efficient coping mechanism with work-related stress, it does not only improve employee's quality of life, but also decreases the cost of health care and productivity of the organization (EU-OSHA, 2012). In fact, by definition, coping refers to an individual's constantly changing cognitive and behavioural efforts in managing his or her external and internal stimuli that are perceived to be above his or her resources (Lazarus \& Folkman, 1984; Folkman et al., 1986). According to Lazarus and Folkman (1987), coping strategies are classified into two dimensions, namely problem-focused and emotion-focused coping. On the one hand, if individuals are capable of taking responsible actions in changing the environment in the future, such as controlling the stressful environment, then it is advisable to use problem-focused coping. On the other hand, it is best to use emotion-focused intervention where emotions can respond better in reducing the emotional discomfort of individuals in a stressful environment (Lazarus \& Folkman, 1984).

In addition to problem-focused and emotion-focused coping, other scholars suggest a diverse range of coping strategies including active coping, planning, suppressing competing activities, seeking instrumental support, seeking social support, positive framing, acceptance, denial, seeking a religious soothing, emotional ventilation, behavioural or mental disengagement (Amirkhan, 1990; Carver et al., 1989; Scheier et al., 1986). In this sense, coping strategies are necessity when dealing with work-related stress and accompanying stressors (Labrague et al., 2016) as well as impacting better outcomes of particular studies.

However, a broader perspective on this concept on stress and coping strategies has not been fully explored in Asian tradition. To date, there is a dearth of knowledge on work-related stress and coping strategies simultaneously involving various occupations within Asian countries. Several systematic reviews of this concept have been identified merely to explore stress and coping strategies among nurses (Labrague et al., 2016; Wazqar et al., 2017; Teixera et al., 2015; Labrague et al., 2018). Therefore, the purpose of this review was to systematically evaluate and 
INTERNATIONAL JOURNAL OF ACADEMIC RESEARCH IN BUSINESS AND SOCIAL SCIENCES

Vol. 10, No. 6, June, 2020, E-ISSN: 2222-6990 @ 2020 HRMARS

synthesize the existing literature in (1) investigating the types of stressors across occupations; and (2) examining the pattern of coping strategies practiced among employees.

\section{Methods}

\section{Design}

This study conducted a systematic literature review by relevant criteria from the Preferred Reporting Items for Systematic Reviews and Meta-Analyses (PRISMA). It consists of five subsections including search strategy, inclusion and exclusion criteria, eligibility, data abstraction and analysis.

\section{Search Strategy}

A systematic search strategy was implemented through three electronic databases, namely Web of Science, Scopus and Medline. The keywords in the titles and abstracts were used in the search process including "stress", "work-related stress", "work stress", "occupational stress", "coping strategies", coping skills", "coping", "cope" and "coping mechanisms". This process yielded a result of 1113 documents from Web of Science (WOS), 2304 documents from Scopus and 2341 documents from Medline databases were retrieved.

\section{Inclusion and Exclusion Criteria}

The first criterion for inclusion concerned a timeline, and a period of ten years, between the year of 2010 to 2020 was selected. The second inclusion criterion was document types, journal (research articles) with empirical data as primary sources were selected. The third inclusion was articles published in the field of social science, organizational psychology, as well as business and management, were selected to increase the possibility of retrieving related articles. The fourth inclusion was regarding on region, where only the Asian region was selected in this review. The fifth was focusing on articles published in English language. The final inclusion was including the selection of samples involving employees across occupations. Meanwhile, the exclusion criteria were systematic review, meta-analysis, chapter in book, review papers, non-research papers, non-English papers and samples other than employees as stated in Table 1. Overall, a total of 5495 articles were excluded based on these criteria, as stated in Figure 1. After the identification process, out of 263 documents to be screened 155 documents were retained for the next stage.

\section{Eligibility}

A total of 57 articles were prepared for the third stage known as the eligibility. Eligibility is a process that includes or excludes articles manually according to the authors' specific criteria. At this stage, the titles, abstracts and the main contents of all the articles were examined thoroughly to ensure that they fulfilled the inclusion criteria and fit to be employed in the present study to achieve the objective of the current research. Before the eligibility process was carried out, the duplicated documents were removed first. A total of 18 articles were traced as similar articles were excluded in both databases for the next phase. Finally, a total of 57 remaining articles are ready to be analyzed. 
INTERNATIONAL JOURNAL OF ACADEMIC RESEARCH IN BUSINESS AND SOCIAL SCIENCES Vol. 10, No. 6, June, 2020, E-ISSN: 2222-6990 @ 2020 HRMARS

Table 1. Inclusion and Exclusion Criteria

\begin{tabular}{|l|l|l|}
\hline Criteria & Inclusion & Exclusion \\
\hline Timeline & Between 2010 to 2020 & $<2010$ \\
\hline Document types & Journal (research articles) & $\begin{array}{l}\text { Systematic review, meta- } \\
\text { analysis, chapter in book, review } \\
\text { papers, non-research papers }\end{array}$ \\
\hline Subject area & $\begin{array}{l}\text { Social Science, Organizational } \\
\text { Psychology, Business and } \\
\text { Management }\end{array}$ & $\begin{array}{l}\text { Other than Social Science, } \\
\text { Organizational Psychology, } \\
\text { Business and Management }\end{array}$ \\
\hline Region & Asian & Other than Asian \\
\hline Language & English & Non-English \\
\hline Sample & Worker, employees & $\begin{array}{l}\text { Students, patients, elderly, } \\
\text { child, parent }\end{array}$ \\
\hline
\end{tabular}

\section{Data Abstraction and Analysis}

The remaining articles were evaluated, reviewed and analyzed after the eligibility process. The data were extracted to identify relevant themes and sub-themes for the present study by reading titles, abstracts and then throughout the full text of articles (in-depth). During the review process, answers were sought by the following: (a) the research design; (b) the type of stress; (c) the type of coping strategies; (d) the sample selection and (e) study region. From the search described above, 57 articles were identified. After reading the abstracts, 20 articles were omitted because they were irrelevant to the research questions. These omitted articles either did not test the relationship between stress and coping strategies or examined stress and coping strategies among students, elderly and patients. After a detailed reading of the full texts, 14 articles remained. The summaries of each articles included in this review were presented in Table $2-7$. 
INTERNATIONAL JOURNAL OF ACADEMIC RESEARCH IN BUSINESS AND SOCIAL SCIENCES Vol. 10, No. 6, June, 2020, E-ISSN: $2222-6990$ ๑ 2020 HRMARS

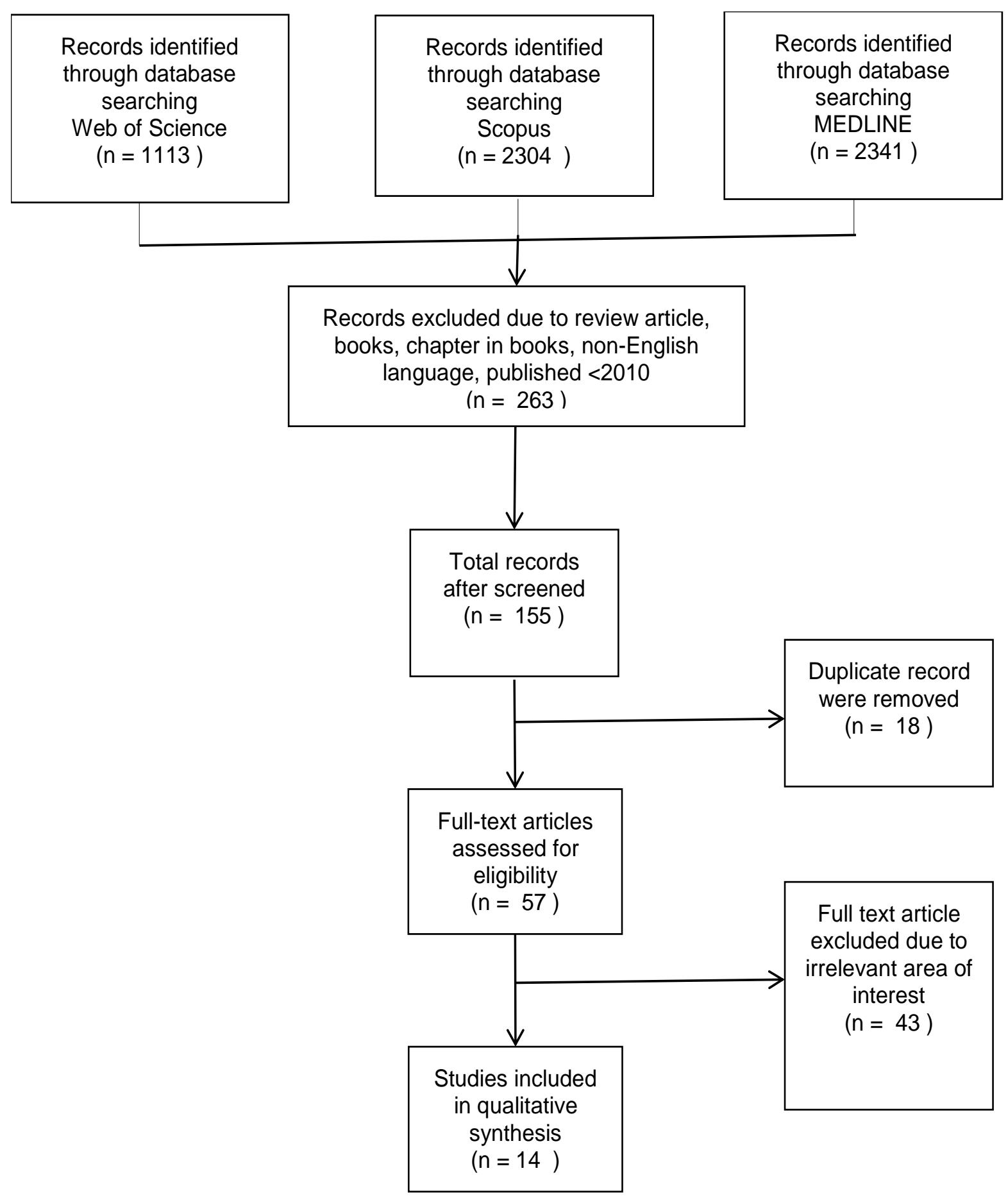

Figure 1: Flow Diagram for the systematic literature review process 
INTERNATIONAL JOURNAL OF ACADEMIC RESEARCH IN BUSINESS AND SOCIAL SCIENCES

Vol. 10, No. 6, June, 2020, E-ISSN: 2222-6990 @ 2020 HRMARS

\section{Results}

The results provided a comprehensive analysis of the present stress, coping strategies and major findings of those studies.

\section{Country Setting and Sample Selection}

Fourteen studies were included in the review. As shown in Table 2, most of the studies reviewed were conducted in China (4), followed by two studies from South Korea, Malaysia and India respectively. Finally, each study from Saudi Arabia, the Philippines, Pakistan and Bangladesh were extracted.

Table 2: Country

\begin{tabular}{lc}
\hline Country & Total \\
\hline China & 4 \\
South Korea & 2 \\
Malaysia & 2 \\
India & 2 \\
Saudi Arabia & 1 \\
Philippine & 1 \\
Pakistan & 1 \\
Bangladesh & 1 \\
\hline
\end{tabular}

Meanwhile, studies on stress and coping strategies have recruited samples selection across various sectors such as nurses, teachers, police officers, bank employees, construction workers and others as stated in details in Table 3.

Table 3: Sample

\begin{tabular}{lc}
\hline Sample & Total \\
\hline Nurses & 2 \\
Teachers & 1 \\
Police Officers & 1 \\
Petroleum Industry Workers & 2 \\
Hotel Employees & 2 \\
IT Employees & 1 \\
Steel Construction Workers & 1 \\
Cable Manufacturing Workers & 1 \\
Rescue Workers & 1 \\
Bank Employees & 1 \\
Academic and Non-Academic Staff & 1 \\
\hline
\end{tabular}

\section{Research Design}

In relations to the research design in table 4, most of the studies used a cross-sectional design (12 articles), while only two studies were used longitudinal research design. 
INTERNATIONAL JOURNAL OF ACADEMIC RESEARCH IN BUSINESS AND SOCIAL SCIENCES

Vol. 10, No. 6, June, 2020, E-ISSN: 2222-6990 @ 2020 HRMARS

Table 4: Research Design

\begin{tabular}{ccc}
\hline \multicolumn{2}{c}{ Research Design } & Total \\
\hline Cross-sectional design & Longitudinal design & \\
\hline 12 & 2 & 14 \\
\hline
\end{tabular}

\section{Work-related Stress}

The review resulted in identifying two types of stress, divided into two main sub-themes being identified, namely tasks and organizational stressors. As shown in table 5, most of the studies ( 7 articles) stipulated that workload was major contributor to tasks stressors across occupations. Other types of stress widely discussed in reviewed studies are role ambiguity (4 articles), responsibility (4 articles), lack of job control (4 articles), working or physical environment (4 articles), participation (3 articles), conflict (3 articles) and interpersonal relationship (3 articles). Other types of stress are less discussed in these reviewed studies, as stated in table 5. Meanwhile, two articles not stated the types of work-related stress in the studies.

As shown in Table 6, most studies (4 articles) stipulated that management is a major contributor to organizational stressors. Followed by organizational system or technology, organizational problem, the closeness of cooperation, work interruption and accident risk with two articles respectively. Meanwhile, each studies for death and dying, occupational climate, political and unprofitability.

\section{Coping Strategies}

According to Table 7, at least eight sub-theme of coping strategies have been identified in this review including problem-focused coping, emotion-focused coping, avoidant-coping, positive coping, negative coping, coping resources, self-care coping, pro-social coping behaviour and other independent coping. As listed in the table, most studies implemented three major coping strategies such as problem-focused coping, emotion-focused coping and coping resources. In problem-focused coping, most studies implemented problem-solving and seeking social support approach (4 articles). Meanwhile, most studies used the avoidance approach in emotion-focused coping (4 articles). Finally, three studies implemented the same coping resources including recreation, self-care, social support and rational coping approach. Meanwhile, other coping strategies were only practiced by one or two times by several studies. However, a study conducted by Mendoza (2019) stated the similar type of coping strategies related to stressors used in the respective study. 
INTERNATIONAL JOURNAL OF ACADEMIC RESEARCH IN BUSINESS AND SOCIAL SCIENCES

Vol. 10, No. 6, June, 2020, E-ISSN: 2222-6990 @ 2020 HRMARS

Table 5: Job Stressors

\begin{tabular}{|c|c|c|c|c|c|c|c|c|c|c|c|c|}
\hline & $\begin{array}{l}\text { Naholi } \\
\text { et al. } \\
2015\end{array}$ & $\begin{array}{l}\text { Mend } \\
\text { o-za } \\
2019\end{array}$ & $\begin{array}{l}\text { Ryu } \\
\text { et al. } \\
2020\end{array}$ & $\begin{array}{c}\text { Li et } \\
\text { al. } \\
2017\end{array}$ & $\begin{array}{c}\text { Xiao et } \\
\text { al. } \\
2017\end{array}$ & $\begin{array}{l}\text { Huang } \\
\text { et al. } \\
2018\end{array}$ & $\begin{array}{c}\text { Kosala } \\
\text { i \& } \\
\text { Mahes } \\
\text {-wari } \\
2018\end{array}$ & $\begin{array}{c}\text { Wida- } \\
\text { jati } \\
2018\end{array}$ & $\begin{array}{l}\text { Rasdi } \\
\& \\
\text { Fadzil } \\
2018\end{array}$ & $\begin{array}{l}\text { Lian } \\
\text { et al. } \\
2017\end{array}$ & $\begin{array}{c}\text { Ukil \& } \\
\text { Ullah } \\
2016\end{array}$ & $\begin{array}{l}\text { Muko- } \\
\text { solu } \\
\text { et al. } \\
2015\end{array}$ \\
\hline Workload & $\sqrt{ }$ & & & $\sqrt{ }$ & $\sqrt{ }$ & & $\sqrt{ }$ & & $\sqrt{ }$ & $\sqrt{ }$ & $\sqrt{ }$ & \\
\hline Job demand & & & $\sqrt{ }$ & & & & & & & & & $\sqrt{ }$ \\
\hline Role ambiguity & & & & & $\sqrt{ }$ & & & & & $\sqrt{ }$ & $\sqrt{ }$ & $\sqrt{ }$ \\
\hline Role insufficiency & & & & & $\sqrt{ }$ & & & & & $\sqrt{ }$ & & \\
\hline Role boundary & & & & & $\sqrt{ }$ & & & & & $\sqrt{ }$ & & \\
\hline Responsibility & & & $\sqrt{ }$ & & $\sqrt{ }$ & & & & & $\sqrt{ }$ & $\sqrt{ }$ & \\
\hline Job decision latitude & & & & & & & & & & & & $\sqrt{ }$ \\
\hline Multitask & & & & & & & $\sqrt{ }$ & & & & & \\
\hline Lack of job control & & & $\sqrt{ }$ & & $\sqrt{ }$ & & & & & $\sqrt{ }$ & $\sqrt{ }$ & \\
\hline Lack of support & $\sqrt{ }$ & & & & & & & & & & & $\sqrt{ }$ \\
\hline Lack of reward & & & $\sqrt{ }$ & & & & & & & & & \\
\hline Teamwork & & & & & & & $\sqrt{ }$ & & & & & \\
\hline Participation & & & & & $\sqrt{ }$ & & & & & $\sqrt{ }$ & $\sqrt{ }$ & \\
\hline $\begin{array}{l}\text { Communication } \\
\text { possibilities }\end{array}$ & & & & & $\sqrt{ }$ & & & & & $\sqrt{ }$ & & \\
\hline Low status & & & & & & & & & & & $\sqrt{ }$ & \\
\hline Job security & & & $\sqrt{ }$ & & & & & & & & & \\
\hline Conflict & $\sqrt{ }$ & & $\sqrt{ }$ & & & & & & & & $\sqrt{ }$ & \\
\hline $\begin{array}{l}\text { Interpersonal } \\
\text { relationship }\end{array}$ & & & & $\sqrt{ }$ & & & & $\sqrt{ }$ & & & $\sqrt{ }$ & \\
\hline supervisory & & $\sqrt{ }$ & & & & & & & & & & $\sqrt{ }$ \\
\hline Personal & & $\sqrt{ }$ & & & & & & & $\sqrt{ }$ & & & \\
\hline $\begin{array}{l}\text { Inadequate } \\
\text { preparation }\end{array}$ & $\sqrt{ }$ & & & & & & & & & & & \\
\hline
\end{tabular}


INTERNATIONAL JOURNAL OF ACADEMIC RESEARCH IN BUSINESS AND SOCIAL SCIENCES

Vol. 10, No. 6, June, 2020, E-ISSN: 2222-6990 @ 2020 HRMARS

\begin{tabular}{|l|l|l|l|l|l|l|l|l|l|l|l|}
\hline $\begin{array}{l}\text { Uncertainty of } \\
\text { treatment }\end{array}$ & $\sqrt{ }$ & & & & & & & & & & \\
\hline Patient care & & & & $\sqrt{ }$ & & & & & & & \\
\hline $\begin{array}{l}\text { Working/physical } \\
\text { environment }\end{array}$ & & & & $\sqrt{ }$ & $\sqrt{ }$ & & & & & $\sqrt{ }$ & $\sqrt{ }$ \\
\hline $\begin{array}{l}\text { Intrinsic } \\
\text { impoverishment }\end{array}$ & & & & & & & & & & & $\sqrt{ }$ \\
\hline Anxious worrying & & & & & & & & & & & \\
\hline Anxiety & & & & & & & & & & & \\
\hline Depression & & & & & & & & & & $\sqrt{ }$ & \\
\hline
\end{tabular}

Table 6: Organizational Stressors

\begin{tabular}{|c|c|c|c|c|c|c|c|c|c|c|c|c|}
\hline & $\begin{array}{l}\text { Naholi } \\
\text { et al. } \\
2015\end{array}$ & $\begin{array}{l}\text { Men- } \\
\text { doza } \\
2019\end{array}$ & $\begin{array}{l}\text { Ryu et } \\
\text { al. } \\
2020\end{array}$ & $\begin{array}{l}\text { Li et } \\
\text { al. } \\
2017\end{array}$ & $\begin{array}{c}\text { Xiao et } \\
\text { al. } \\
2017\end{array}$ & $\begin{array}{l}\text { Huang } \\
\text { et al. } \\
2018\end{array}$ & $\begin{array}{c}\text { Kosala } \\
\text { i \& } \\
\text { Mahes } \\
\text { wari } \\
2018\end{array}$ & $\begin{array}{c}\text { Widaj } \\
\text { ati } \\
2018\end{array}$ & $\begin{array}{c}\text { Rasdi } \\
\& \\
\text { Fadzil } \\
2018\end{array}$ & $\begin{array}{c}\text { Lian et } \\
\text { al. } \\
2017\end{array}$ & $\begin{array}{l}\text { Ukil \& } \\
\text { Ullah } \\
2016\end{array}$ & $\begin{array}{c}\text { Mukos } \\
\text { olu et } \\
\text { al. } \\
2015\end{array}$ \\
\hline Death \& dying & $\sqrt{ }$ & & & & & & & & & & & \\
\hline $\begin{array}{l}\text { Org. system / } \\
\text { technology }\end{array}$ & & & $\sqrt{ }$ & & & & $\sqrt{ }$ & & & & & \\
\hline Management & & $\sqrt{ }$ & & $\sqrt{ }$ & & & $\sqrt{ }$ & $\sqrt{ }$ & & & & \\
\hline $\begin{array}{l}\text { Organizational } \\
\text { problem }\end{array}$ & & & & & $\sqrt{ }$ & & & & & $\sqrt{ }$ & & \\
\hline $\begin{array}{l}\text { Closeness of } \\
\text { cooperation }\end{array}$ & & & & & $\sqrt{ }$ & & & & & $\sqrt{ }$ & & \\
\hline Accident risk & & & & & $\sqrt{ }$ & & & & & $\sqrt{ }$ & & \\
\hline
\end{tabular}


INTERNATIONAL JOURNAL OF ACADEMIC RESEARCH IN BUSINESS AND SOCIAL SCIENCES

Vol. 10, No. 6, June, 2020, E-ISSN: 2222-6990 @ 2020 HRMARS

Table 7: Coping strategies

\begin{tabular}{|c|c|c|c|c|c|c|c|c|c|c|c|c|c|}
\hline & $\begin{array}{l}\text { Naho- } \\
\text { li } \\
\text { et al. } \\
2015\end{array}$ & $\begin{array}{l}\text { Ryu } \\
\text { et al. } \\
2020\end{array}$ & $\begin{array}{c}\text { Li et } \\
\text { al. } \\
2017\end{array}$ & $\begin{array}{c}\text { Xiao } \\
\text { et al. } \\
2017\end{array}$ & $\begin{array}{l}\text { Hu- } \\
\text { ang } \\
\text { et al. }\end{array}$ & $\begin{array}{l}\text { Kosa- } \\
\text { lai \& } \\
\text { Mahe } \\
\text { swari } \\
2018\end{array}$ & $\begin{array}{c}\text { Wida- } \\
\text { jati } \\
2018\end{array}$ & $\begin{array}{c}\text { Rasdi } \\
\text { \&Fad- } \\
\text { zil } \\
2018\end{array}$ & $\begin{array}{c}\text { Jamal } \\
2017\end{array}$ & $\begin{array}{l}\text { Lian } \\
\text { et al. } \\
2017\end{array}$ & $\begin{array}{l}\text { Ukil \& } \\
\text { Ullah } \\
2016\end{array}$ & $\begin{array}{c}\text { Muko } \\
\text { solu } \\
\text { et al. } \\
2015\end{array}$ & $\begin{array}{l}\text { Choi } \\
\text { et al. } \\
2019\end{array}$ \\
\hline \multicolumn{14}{|l|}{ Problem-focused coping } \\
\hline Problem solving & & $\sqrt{ }$ & & & $\sqrt{ }$ & & $\sqrt{ }$ & $\sqrt{ }$ & & & & & \\
\hline Active coping planning & & & & & & & & & $\sqrt{ }$ & & & & $\sqrt{ }$ \\
\hline Suppression & & & & & & & & & $\sqrt{ }$ & & & & \\
\hline $\begin{array}{l}\text { Instrumental/social } \\
\text { support }\end{array}$ & & & & & $\sqrt{ }$ & & & $\sqrt{ }$ & & & & $\sqrt{ }$ & $\sqrt{ }$ \\
\hline \multicolumn{14}{|l|}{ Emotion-focused coping } \\
\hline $\begin{array}{l}\text { Positive } \\
\text { reinterpretation }\end{array}$ & & & & & & & & & $\sqrt{ }$ & & & $\sqrt{ }$ & \\
\hline Restraint & & & & & & & & & $\sqrt{ }$ & & & & \\
\hline Acceptance & & & & & & & & & $\sqrt{ }$ & & & & \\
\hline Religion & & & & & & & & & $\sqrt{ }$ & & & & \\
\hline Avoidance & & $\sqrt{ }$ & & & $\sqrt{ }$ & & & $\sqrt{ }$ & & & & & $\sqrt{ }$ \\
\hline $\begin{array}{l}\text { Focus/venting of } \\
\text { emotion }\end{array}$ & & $\sqrt{ }$ & & & & & & & & & & $\sqrt{ }$ & \\
\hline $\begin{array}{l}\text { Behavioural } \\
\text { disengagement }\end{array}$ & & & & & & & & & & & & $\sqrt{ }$ & \\
\hline \multicolumn{14}{|l|}{ Avoidant-coping } \\
\hline $\begin{array}{l}\text { Behavioural } \\
\text { disengagement }\end{array}$ & & & & & & & & & $\sqrt{ }$ & & & & \\
\hline Denial & & & & & & & & & $\sqrt{ }$ & & & $\sqrt{ }$ & \\
\hline Mental disengagement & & & & & & & & & $\sqrt{ }$ & & & & \\
\hline Self-distraction & & & & & & & & & & & & $\sqrt{ }$ & \\
\hline
\end{tabular}


INTERNATIONAL JOURNAL OF ACADEMIC RESEARCH IN BUSINESS AND SOCIAL SCIENCES

Vol. 10, No. 6, June, 2020, E-ISSN: 2222-6990 @ 2020 HRMARS

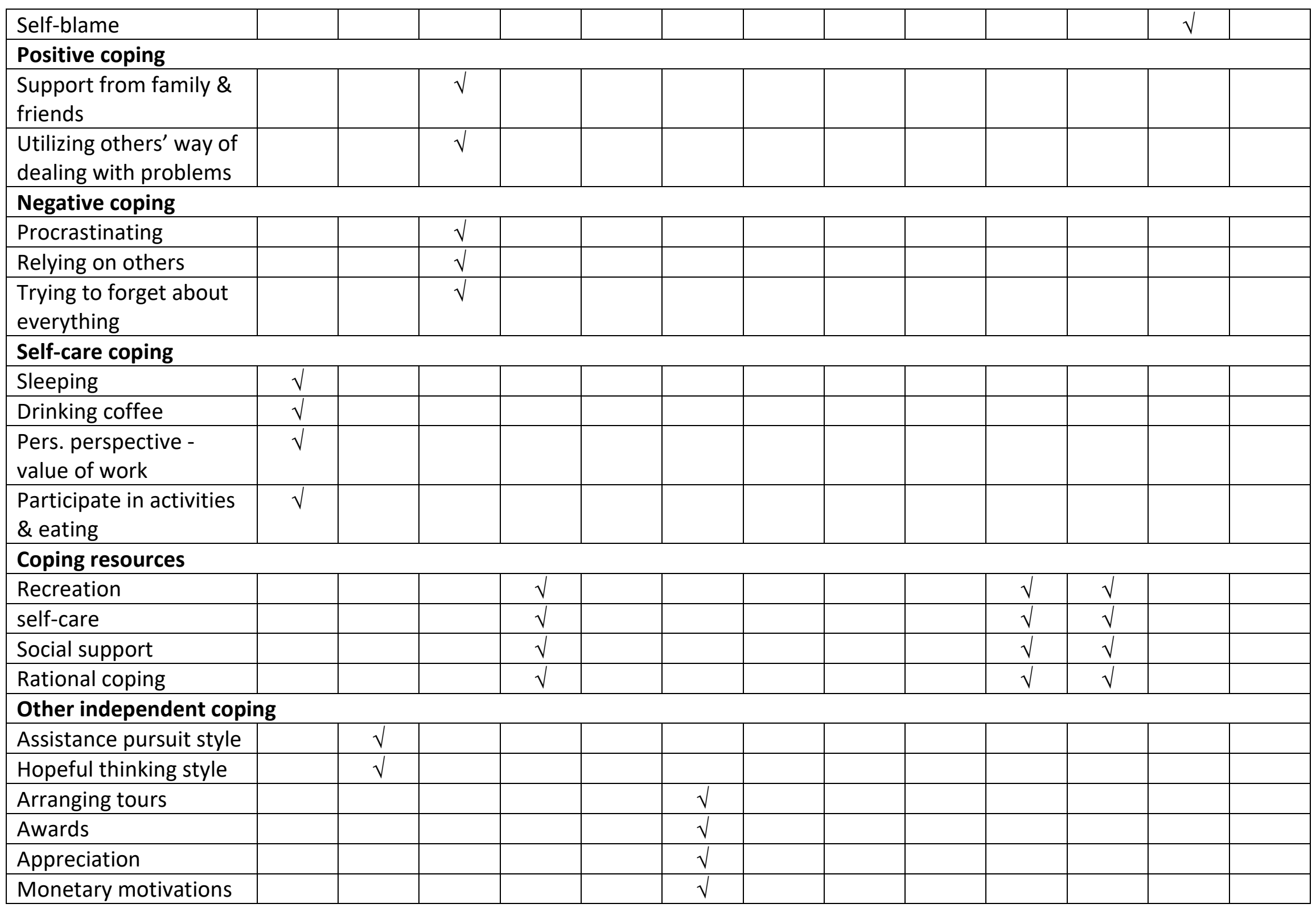


INTERNATIONAL JOURNAL OF ACADEMIC RESEARCH IN BUSINESS AND SOCIAL SCIENCES Vol. 10, No. 6, June, 2020, E-ISSN: 2222-6990 @ 2020 HRMARS

\section{Discussions}

This review identified the types of work-related stress, its stressors and coping strategies used by various occupations across Asia. As stipulated in the review results, most studies conducted in China involved various occupations including nurses, hotel employees and petroleum industry workers (Li et al., 2017; Xiao et al., 2017; Huang et al., 2018; Lian et al., 2017). While other countries were utilized different samples such as teachers, police officers, IT employees, bankers, rescue workers, academic and non-academic staff, construction and manufacturing workers (Naholi et al., 2015; Mendoza, 2019; Ryu et al., 2020; Kosalai \& Maheswari, 2018; Widajati, 2018; Rasdi \& Fadzil, 2018; Jamal, 2017; Ukil and Ullah, 2016; Mukosolu et al., 2015; Choi et al., 2019). In this sense, the utilized sample of this review, limiting the generalizability of findings and additional inclusion of other occupations from different settings may require providing more generalizable findings.

Concerning the research design, the researcher found that most studies were cross-sectional dominated by self-reported data (Naholi et al., 2015; Mendoza, 2019; Ryu et al., 2020; Li et al., 2017; Kosalai \& Maheswari, 2018; Huang et al., 2018; Widajati, 2018; Rasdi \& Fadzil, 2018; Jamal, 2017; Ukil and Ullah, 2016; Mukosolu et al., 2015; Choi et al., 2019). Only two related studies used longitudinal research design in this review (Lian et al., 2017; Xiao et al., 2017). This may be because this design is more convenient and easier to be conducted at one time as compared to longitudinal design. However, this study may involve common method bias in considering the nature of stress experiences. In fact, Lazarus and Folkman (1987) argue that stress may change across time and since they were asked to recall their previous stressful experiences, they may not be able to recall some of these stressful experiences. The use of a longitudinal study may be necessary to detect changes for stress and coping abilities across a few months.

The synthesis of this review was difficult to quantify because of the great number of stressors, and coping strategies were identified, thus creating a variation on the following themes. Although, some scholars claimed that work-related stressors are identified in three main categories, including the job, the team and the organizational level (Salin \& Hoel, 2011; Samnani \& Singh, 2012), this review only focused on two sub-themes. The current review revealed that the main job stressors across occupations generally originated from heavy workload, role ambiguity, responsibility, lack of job control and poor physical environment (Naholi et al., 2015; Li et al., 2017; Xiao et al., 2017; Kosalai \& Maheswari, 2018; Rasdi \& Fadzil, 2018; Lian et al., 2017; Ukil \& Ullah, 2016). Meanwhile, management issues were a major contributor to organizational stressors across occupations (Mendoza, 2019; Li et al., 2017; Kosalai \& Maheswari, 2018; Widajati, 2018). In line with previous reviews, the workload is considered as one the most often-cited job stressors across occupations (Van den Brande et al., 2016; Wazqar et al., 2017).

Several coping strategies were mentioned in this review to address work-related stress across various occupations. Most studies implemented three major coping strategies, problem-focused coping (Ryu et al., 2020; Huang et al., 2018; Widajati 2018; Rasdi \& Fadzil, 2018; Jamal, 2017; Mukosolu et al., 2015; Choi et al., 2019), emotion-focused coping (Ryu et al., 2020; Huang et al., 2018; Rasdi \& Fadzil, 2018; Jamal, 2017; Mukosolu et al., 2015; Choi et al., 2019) and coping resources (Xiao et al., 2017; Lian et al., 2017; Ukil \& Ullah, 2016). As listed, similar studies were identified the used of problemfocused and emotion-focused coping simultaneously. These coping strategies are in line with popular 
strategies mainly proposed by Lazarus and Folkman (1987), in which employees prefer to adjust their activities in managing problems within the environment and take action to change the individual attitude towards emotions (Lazarus, 2000; Lazarus and Folkman, 1987). Besides, in line with the previous review conducted by Vand den Brande et al. (2016), coping resources are also included as part of coping strategies, in which it impacts the tendency to conduct a certain coping strategy (Lazarus \& Folkman, 1984; Jerusalem, 1993).

\section{Limitations and Recommendations}

The divergence of the reviewed studies in terms of sample characteristics, instruments, data collection tools, and operational definitions of the study variables may have led to difficulties in attempting to generalize the results. Also, there is limited evidence in using a longitudinal design to measure this phenomenon, and no further discussion involving common method bias for the crosssectional design for this review studies. A future recommendation should include the discussion on several methodological limitations that were not adequately investigated in this review, such as combining qualitative, mixed-method, experimental research designs. Besides, the range of years should be lengthier than ten years and the impact of stress and coping strategies on work and healthrelated outcomes.

\section{Conclusion}

This review provides a systematic way of understanding the relationship between work-related stress and coping strategies, specifically across different sources of data, different research designs and analysis. This systematic review hopefully could facilitate future researchers in providing better understandings on work-related stressors and make more sense to the relevance coping services to be implemented in reducing these stressors. The review offers several recommendations for future studies such as involving more samples across occupations within the lengthier times. It is also suggested to discussing more methodological matters in a future review including longitudinal, qualitative, mixed-method, experimental research designs. Finally, more research should be conducted in the context of stress and coping strategies, given the determination in addressing work and health-related outcomes of employees.

\section{Corresponding Author}

Farah Shazlin Johari, Faculty of Business and Management, Universiti Teknologi MARA, Malaysia

Email: farahshazlin@uitm.edu.my

\section{References}

Bahari, F., Tan, A. L., \& Wider, W. (2016). The Effect of Occupational Stress on Teachers' Psychological Well-Being: Social Support as Moderator. Australian Journal of Basic and Applied Sciences, 10 (4), 56-65.

Carver, C., Scheier, M., \& Weintraub, J. (1989). Assessing coping strategies: A theoretically based approach. Journal of Personality and Social Psychology, 56(2), 267-283. 
INTERNATIONAL JOURNAL OF ACADEMIC RESEARCH IN BUSINESS AND SOCIAL SCIENCES Vol. 10, No. 6, June, 2020, E-ISSN: 2222-6990 @ 2020 HRMARS

Choi, H.-M., Mohammad, A. A. A., \& Kim, W. G. (2019). Understanding hotel frontline employees' emotional intelligence, emotional labor, job stress, coping strategies and burnout. International Journal of Hospitality Management, 82, 199-208.

EU-OSHA. (2012). Management of Psychosocial Risks at Work: An Analysis of The Finding of The European Survey of Enterprises on New and Emerging Risks (ESENER). Luxembourg: Publications Office of the European Union.

Folkman, S., Lazarus, R. S., Dunkel-Scetter, C., DeLongis, A., \& Gruen, R. J. (1986). Dynamics of a stressful cognitive appraisal, coping, and encounter outcomes. Journal of Personality and Social Psychology, 50(5), 992-1003.

Huang, S. S., Van der Veen, R., \& Song, Z. (2018): The impact of coping strategies on occupational stress and turnover intentions among hotel employees. Journal of Hospitality Marketing \& Management, 1-20.

Jamal, Y. (2017). Coping strategies as a mediator of hardiness and stress among rescue workers. Studies on Ethno-Medicine, 11(3), 201-208.

Jerusalem. (1993). Personal resources, environmental constraints, and adaptational processes: The predictive power of a theoretical stress model. Personality and Individual Differences, 14(1), $15-24$.

Kamarulzaman, K. A., Zulkifly S. S., \& Hasan N. H. (2017). Occupational stress among a cancer hospital nurses. Human Factors and Ergonomics Journal, 2(3), $12-20$.

Khan, J. H. A. (1990). A factor analytically derived measure of coping: The coping strategy indicator. Journal of Personality and Social Psychology, 59(5), 1066-1074.

Kosalai, S., \& Maheswari, G. S. (2018). Stress level and coping strategies of IT sectors. Indian Journal of Public Health Research and Development, 9(11), 71-76.

Labrague, L. J., McEnroe-Petitte, D. M., De Los Santos, J. A. A., \& Edet, O. B. (2018). Examining stress perceptions and coping strategies among Saudi nursing students: A systematic review. Nurse Education Today, 65, 192-200.

Labrague, L. J., McEnroe-Petitte, D. M., Gloe, D., Thomas, L., Papathanasiou, I. V., \& Tsaras, K. (2016): A literature review on stress and coping strategies in nursing students. Journal of Mental Health, 1-10.

Larson, L. L. (2004). Internal auditors and job stress. Managerial Auditing Journal, 19(9), 1119-1130.

Lazarus, R. S. (2000). Toward better research on stress and coping. American Journal of Psychology, 55(6), 665-673.

Lazarus, R. S., \& Folkman, S. (1987). Transactional theory and research on emotions and coping. European Journal of Person Centered Healthcare, 1, 141-69.

Lazarus, R. S., \& Folkman, S. (1984). Stress, appraisal, and coping. New York, NY: Springer.

Lian, Y., Gu, Y., Han, R., Jiang, Y., Guan, S., Xiao, J. \& Liu, J. (2016). Effect of changing work stressors and coping resources on psychological distress. Journal of Occupational and Environmental Medicine, 58(7), 256-263.

Li, L., Ai, H., Gao, L., Zhou, H., Liu, X., Zhang, Z., Sun, T., \& Fan, L. (2017). Moderating effects of coping on work stress and job performance for nurses in tertiary hospitals: a cross-sectional survey in China. BMC Health Services Research, 17, 401.

Mendoza, R. D. Jr. (2019). Verbal English fluency, workplace stress and coping mechanism of secondary school faculty in Sulu. The Asian EFL Journal, 21(2), 78-100. 
INTERNATIONAL JOURNAL OF ACADEMIC RESEARCH IN BUSINESS AND SOCIAL SCIENCES Vol. 10, No. 6, June, 2020, E-ISSN: 2222-6990 @ 2020 HRMARS

Mukosolu, O., Ibrahim, F., Rampal, L., \& Ibrahim, N. (2015). Prevalence of job stress and its associated factors among Universiti Putra Malaysia staff. Malaysian Journal of Medicine and Health Sciences, 11(1), 27-38.

Naholi, R. M., Nosek. C. L., Somayaji, D. (2015). Stress among new oncology nurses. The Clinical Journal of Oncology Nursing, 19(1),115-117.

National Institute for Occupational Health and Safety (NIOSH). Stress at work. Retrieved from https://www.cdc.gov/niosh/docs/99-101/default.html

Park, Y. M., \& Kim, S. Y. (2013). Impacts of Job Stress and Cognitive Failure on Patient Safety Incidents among Hospital Nurses. Safety and health at work, 4(4), 210-215.

Rasdi, I., \& Fadzil, F. F. (2018). The association between noise, work stress and coping with sleep quality among cable manufacturing workers. Future of food: Journal of food, agriculture and society, 6, 108-111.

Reddy, G. L., \& Poornima R. (2012). Occupational Stress and Professional Burnout of University Teachers in South India. International Journal of Educational Planning \& Administration, 2(2), 109-124.

Ren, Y., Zhou, Y., Wang, S., Luo, T., Huang, M., \& Zeng, Y. (2017). Exploratory study on resilience and its influencing factors among hospital nurses in Guangzhou, China. International journal of nursing sciences, 5(1), 57-62.

Ryu, G. W., Yang, Y. S., \& Choi, M. (2020). Mediating role of coping style on the relationship between job stress and subjective well-being among Korean police officers. BMC Public Health, 20, 470.

Sackey, J., \& Sanda M. A. (2009). Influence of occupational stress on the mental health of Ghanaian professional women. International Journal of Industrial Ergonomics, 39(5), 876-887.

Salin, D., Hoel, H., Hoel, H., \& Zapf, D. (2011). Organisational causes of workplace bullying. In S. Einarsen, \& C. L. Cooper (Eds.), Bullying and Harassment in the Workplace: Developments in Theory, Research, and Practice. Boca Raton: Taylor \& Francis Group.

Samnani, A. S., \& Singh, P. (2012). 20 years of workplace bullying research: A review of the antecedents and consequences of bullying in the workplace. Aggression and Violent Behavior, 17, 581-589.

Scheier, M. F., Weintraub, J. K., \& Carver, C. S. (1986). Coping with stress: Divergent strategies of optimists and pessimists. Journal of Personality and Social Psychology, 51(6), 1257-1264.

Teixeira, C. A. B., Pereira, S. S., Cardoso, L., Seleghim, M. R., Reis, L. N., Gherardi-Donato, E. C. S. G. (2015) Occupational stress among nursing technicians and assistants: coping focused on the problem. Investigacion y Educacion en Enfermeria, 33(1), 28-34.

Teixeira, C. A. B., Reisdorfer, E., Gherardi-Donato, E. C. S. (2014). Estresse Ocupacional e Coping: reflexão acerca dos conceitos e a prática de enfermagem hospitalar. Rev Enferm UFPE Online, 8(1), 2528-2532.

Tuckey, M. R., Searle, B. J., Boyd, C. M., Winefield, A. H., \& Winefield, H. H. (2015). Hindrances are not threats: advancing the multidimensionality of work stress. Journal of Occupational Health Psychology, 20(2), 131-147.

Ukil, M. I., \& Ullah, M. S. (2016). Effect of occupational stress on personal and professional life of bank employees in Bangladesh: Do coping strategies matter. Journal of Psychology and Educational Research, 24(2), 75-100. 
INTERNATIONAL JOURNAL OF ACADEMIC RESEARCH IN BUSINESS AND SOCIAL SCIENCES

Wazqar, D. Y., Kerr, M., Regan, S., \& Orchard, C. (2017). An integrative review of the influence of job strain and coping on nurses' work performance: Understanding the gaps in oncology nursing research. International Journal of Nursing Sciences, 4(4), 418-429.

Widajati, N. (2018). Problem focus coping model to face working environment stressors prevents unsafe action among workers in a steel construction plant. Indian Journal of Public Health Research and Development, 9(9), 82-88.

Xiao, J., Guan, S., Ge, H., Tao, N., Zhang, Y., Jiang, Y., Ning, L., Liu, J., \& Lian, Y. (2017). The impact of changes in work stressors and coping resources on the risk of new-onset suicide ideation among Chinese petroleum industry workers. Journal of Psychiatric Research, 88, 1-8.

Yang, T., Guo, Y., Ma, M., Li, Y., Tian, H., Deng, J. (2017). Job Stress and Presenteeism among Chinese Healthcare Workers: The Mediating Effects of Affective Commitment. International Journal of Environmental Research and Public Health, 14(9), 978.

Yim, H.-Y., Seo, H.-J., Cho, Y., \& Kim J. (2017). Mediating Role of Psychological Capital in Relationship between Occupational Stress and Turnover Intention among Nurses at Veterans Administration Hospitals in Korea. Asian Nursing Research, 11(1), 6-12. 